\title{
成人の細胞に胚性幹細胞のパワーを授ける
}

\section{Simple recipe gives adult cells embryonic powers}

Nature Vol. 442(11)/ 6 July 2006

Erika Check

成人の細胞を初期化し、損傷を受けた 組織や臓器の修復に用いる。もしかし たら、これは考えられているほどむず かしいことではないのかもしれない。 このほど考案された化合物混合液を用 いると、成体マウス細胞が胚性幹細胞 (ES 細胞) のようになり、しかもその 作り方は驚くほど簡単だという。

ヒ卜胚性幹細胞は生体內のあらゆる種 類の細胞となることができ(「多能性」 とよばれる，、研究用にも医療用にも極 めて価値あるものと考えられている。し かし、これをヒトの胚から取り出すこと については、多くの国で議論の決着がつ いていない。この倫理的な問題を回避す るため、研究者たちはこのような細胞を 別の材料から得るための研究に取り組ん でいる（Nature 441，1038；2006を参 照)。そうしたなかで、胚とは無関係に 成人の細胞を胚のような状態に初期化で きる化合物配合法の可能性ほど、この領 域を大きく活気づける話はない。

そしてこのほど、京都大学の山中伸弥 たちは、少なくともマウスで有効とみら れるこうした配合法の、初めての有力な たたき台を編み出した。山中たちによれ ば、必要な化合物はわずか 4 種類。実験 に用いた線維芽細胞は分裂周期の短い成 体細胞で、本来ほかの数種類の細胞を生 ずる能力をもつ。そしてこの線維芽細胞 に先の 4 因子を加えると、細胞の外見と 挙動がマウス胚性幹細胞と極めて類似し たものになったという。「可能性としては、 この 4 因子をヒト細胞に与えることで、 倫理的問題を回避しながら多能性細胞が 得られると考えられる」と山中は話す。

初期化した細胞は、「幹細胞性」に関 する数々の厳しい試験をクリアすること
がわかった。胚性幹細胞が発現する重要 遺伝子のいくつかを発現しているととも に、生体の主要な 3 細胞系統を生じさせ ることができ、自身と同様の細胞にも分 裂できた。山中は初期化されたこの細胞 を、「胚性幹細胞様細胞」とよぶ。

\section{幸運と熟練}

山中は今回の成果について、6月 30 日 の国際幹細胞研究学会（カナダ、トロン ト) で発表し、成功には忍耐と工夫と幸 運が必要だったと明かした。幹細胞の 多能性を保つための因子として、山中ら は 5 年をかけて 24 種類の候補物質を選 び出した。さらに幹細胞でのみ活動する 遺伝子が働かない場合には薬剤によって 死んでしまうよう、成体マウス細胞の遺 伝子操作を行った。そうしたうえで、遺 伝子操作したこのマウス細胞に候補因子 24 種類の遺伝子を導入し、薬剤を投与 した。その結果、死滅しなかったのは幹 細胞様細胞だけであった。

山中らは 1 回に 1 個ないし数個の遺伝 子を除去してこの実験を繰り返し、最終的 に不可欠な化合物を 4 種類に絞り込んだ。 このうち 3 因子 (Oct4、Sox2、c-Myc) は、 幹細胞性に重要であることがすでに知ら れていた。しかし、4 個目の因子は意外な ものだったという。しかし、幹細胞研究の 競争は極めて激しいため、科学誌に正式 に発表できるまでこの物質の名前を明か すのは控えたいと山中は話す。

山中の成果は、どの因子が初期化に重 要であるかを確かめようとしてきた先行 研究に連なるものだ。例えばプリンスト ン大学（米国、ニュージャージー州）の Ihor Lemischka たちは、マウス胚性幹細 胞で遺伝子 70 個を検討している (J. Silva et al. Nature doi:10.1038/nature04914; 2006)。また、エディンバラ大学 (英国) の Austin Smith たちは、Nanog とよばれ るタンパク質を研究している (N. Ivanova et al. Nature doi:10.1038/ nature04915; 2006)。「初期化に必要な因子を示した研 究はこれまでいくつかありましたが、十分 な因子を明らかにした研究はありませんで した」と山中はいう。

山中の成果が感嘆と驚きをもって迎え られたのは、重要な因子の候補物質 24 種類に山中がすべてをかけたことによる 部分が大きい。「山中はホームランを打っ たようなものだ」と Lemischka は話す。

しかし研究者たちは、山中の論文は脆 性幹細胞研究の必要性を否定するもので はないと指摘する。なによりもこの 4 因 子に関しては、ヒト細胞での検討が必要 である。また、初期化された細胞が幹細 胞と同じすべての働きをもっているのか 確認がすんだわけではない。実際のとこ ろ、発現する遺伝子に同じものは多いが、 異なるものもまた多い。

山中の報告は、米国上院が今年後半の 胚性幹細胞研究の規制緩和に関して採決 を行うと発表した翌日に行われた。初期 化の進展によって胚性幹細胞研究は不要 になったという主張もあり、山中の論文 はそうした主張を支持するために利用さ れる可能性もある。しかしトロントの学 会の参加者は、それは違うと語る。

Lemischkaも、「そのようにいう人 はいるだろうが、それは間違いだ」と 話す。「この細胞を理解するためにはさ らに研究を重ねる必要がある。山中の 研究に信頼性はあるが、だからといっ て初期化の問題が解決されたとする見 方は決して正しくない」 